This item was submitted to Loughborough's Research Repository by the author.

Items in Figshare are protected by copyright, with all rights reserved, unless otherwise indicated.

\title{
Polymer electrolyte fuel cell transport mechanisms: a universal modelling framework from fundamental theory
}

PLEASE CITE THE PUBLISHED VERSION

\section{PUBLISHER}

(C) IMechE / Professional Engineering Publishing

\section{VERSION}

VoR (Version of Record)

\section{LICENCE}

CC BY-NC-ND 4.0

\section{REPOSITORY RECORD}

Rama, Pratap, Rui Chen, and R.H. Thring. 2009. "Polymer Electrolyte Fuel Cell Transport Mechanisms: A Universal Modelling Framework from Fundamental Theory". figshare. https://hdl.handle.net/2134/4498. 
This item was submitted to Loughborough's Institutional Repository (https://dspace.lboro.ac.uk/) by the author and is made available under the following Creative Commons Licence conditions.

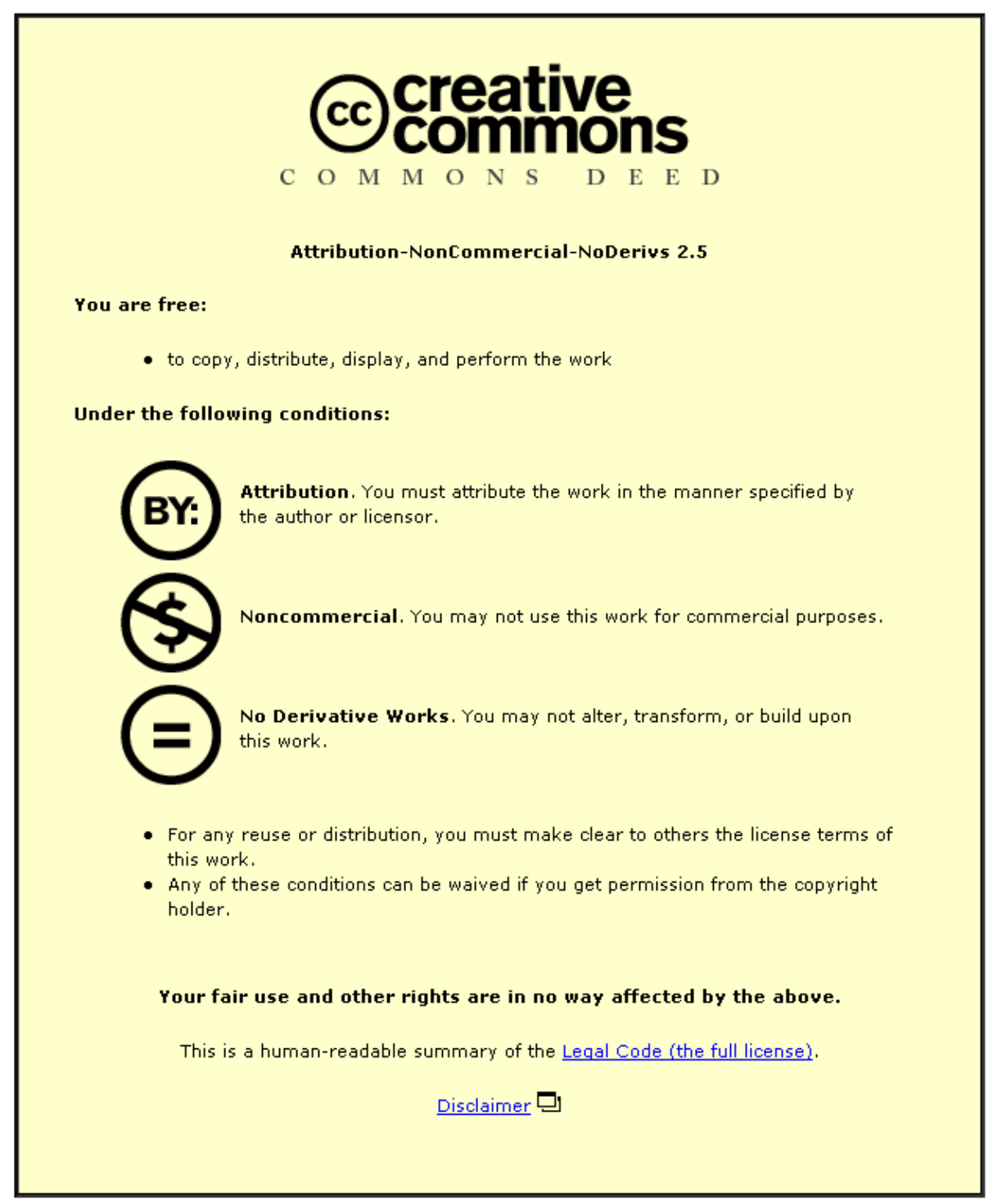

For the full text of this licence, please go to: http://creativecommons.org/licenses/by-nc-nd/2.5/ 


\title{
Polymer electrolyte fuel cell transport mechanisms: a universal modelling framework from fundamental theory
}

\author{
P Rama, R Chen*, and R Thring \\ Department of Aeronautical and Automotive Engineering, Loughborough University, Leicestershire, UK
}

The manuscript was received on 5 July 2005 and was accepted after revision for publication on 28 April 2006.

DOI: 10.1243/09576509JPE212

\begin{abstract}
A mathematical multi-species modelling framework for polymer electrolyte fuel cells (PEFCs) is presented on the basis of fundamental molecular theory. Characteristically, the resulting general transport equation describes transport in concentrated solutions and also explicitly accommodates for multi-species electro-osmotic drag. The multi-species nature of the general transport equation allows for cross-interactions to be considered, rather than relying upon the superimposition of Fick's law to account for the transport of any secondary species in the membrane region such as hydrogen. The presented general transport equation is also used to derive the key transport equations used by the historically prominent PEFC models. Thus, this work bridges the gap that exists between the different modelling philosophies for membrane transport in the literature. The general transport equation is then used in the electrode and membrane regions of the PEFC with available membrane properties from the literature to compare simulated one-dimensional water content curves, which are compared with published data under isobaric and isothermal operating conditions. Previous work is used to determine the composition of the humidified air and fuel supply streams in the gas channels. Finally, the general transport equation is used to simulate the crossover of hydrogen across the membrane for different membrane thicknesses and current densities. The results show that at $353 \mathrm{~K}, 1 \mathrm{~atm}$, and $1 \mathrm{~A} / \mathrm{cm}^{2}$, the nominal membrane thickness for less than $5 \mathrm{~mA} / \mathrm{cm}^{2}$ equivalent crossover current density is $30 \mu \mathrm{m}$. At $3 \mathrm{~atm}$ and $353 \mathrm{~K}$, the nominal membrane thickness for the same equivalent crossover current density is about $150 \mu \mathrm{m}$ and increases further to $175 \mu \mathrm{m}$ at $383 \mathrm{~K}$ with the same pressure. Thin membranes exhibit consistently higher crossover at all practical current densities compared with thicker membranes. At least a 50 per cent decrease in crossover is achieved at all practical current densities, when the membrane thickness is doubled from 50 to $100 \mu \mathrm{m}$.
\end{abstract}

Keywords: polymer electrolyte fuel cell, modelling, multi-species general transport equation, concentrated solution theory, dilute solution theory, electro-osmotic drag, $\mathrm{H}_{2}$ crossover

\section{INTRODUCTION}

Through significant improvements in the design and performance of PEFCs, the technology is being progressively brought ever closer to full-scale

\footnotetext{
${ }^{*}$ Corresponding author: Department of Aeronautical and Automotive Engineering, Loughborough University, Stewart Miller Building, Loughborough, Leicestershire LE11 3TU, UK. email: r.chen@lboro.ac.uk
}

commercialization. The progress has been brought about through the significant levels of experimental-based and simulation-based research and development conducted over the past four decades [1] However, it is recognized that there are still several critical areas that remain problematic in relation to cell design and performance, three of which are discussed below.

The first critical issue is that of water management, which has been the focus of many activities to date [2]. PEFCs are generally characterized by 
perflourinated sulfonic acid (PFSA) membranes, which typically operate at around $353 \mathrm{~K}$. At such temperature, however, water is likely to exist in both liquid and vapour phase. Liquid phase water can be detrimental to cell performance and is likely to form primarily in and around the cathode catalytic region of the cell. Here, liquid water would impede the reactant gas from reaching the active catalyst sites. On the other hand, the PFSA membranes rely upon the presence of water for ionic conductivity. Too little water would therefore cause the membrane to operate in a relatively dry state, thereby increasing the electrical resistance in that electrolytic region.

The second critical issue is that regarding the effects of impurity contamination. To date, much of the work has focused around the tolerance of PEFCs to CO in the reformer feed [3-11]; reforming $\mathrm{H}_{2}$ from a hydrocarbon, such as methanol, will yield variable concentrations of $\mathrm{CO}$. This $\mathrm{CO}$ adsorbs more readily onto the platinum $(\mathrm{Pt})$-based catalytic alloy at the anode, thereby reducing the available surface area for $\mathrm{H}_{2}$ adsorption [3]. In reality, it is likely that the cathode side of air-fed PEFCs is likely to be exposed to atmospheric impurities, which also degrade cell performance. While this is an important issue for commercial civilian outdoor applications, the consequences of atmospheric battlefield contaminants are more serious for military applications [12]. In addition, Okada $[\mathbf{1 3}, \mathbf{1 4}]$ showed that the effects of exposure to impurity ions through either the anode or the cathode side of the cell would alter the properties of the membrane region and thereby affect water management. In essence, the PEFC would operate under true multi-species conditions and the constituents of the fuel and/or air supply can adversely affect both the performance of the catalyst layer and the membrane region.

The third issue concerns the crossover of fuel across the electrolytic membrane. For a PEFC, $\mathrm{H}_{2}$ that crosses over is oxidized at the cathode side, creating excess water. Most significantly, $\mathrm{H}_{2}$ crossover amounts to an equivalent loss in current density, which has the overall impact of reducing fuel cell efficiency. $\mathrm{H}_{2}$ and $\mathrm{O}_{2}$ permeation in the electrolytic membrane region has been discussed in relatively simple terms in the literature $[\mathbf{1 5}, \mathbf{1 6}]$.

It has been identified that one potential remedy to the first two issues is the transition to higher operating temperatures, above $373 \mathrm{~K}$ [17]. As PFSA membranes are typically limited to $383 \mathrm{~K}$, new phosphoric acid-doped polybenzimidazole (PBI) membranes have been synthesized, which can operate up to around $473 \mathrm{~K}$. The acid-doped PBI membrane can achieve $>0.06 \mathrm{~S} \mathrm{~cm}^{-1}$ conductivity with less than 10 per cent relative humidity $(\mathrm{RH})$ at
$473 \mathrm{~K}$ whereas the PFSA membrane would require $>70$ per cent $\mathrm{RH}$ to achieve the same conductivity at $353 \mathrm{~K} \mathrm{[17].} \mathrm{The} \mathrm{tolerance} \mathrm{to} \mathrm{CO} \mathrm{poisoning} \mathrm{is} \mathrm{also}$ much improved; operation above $1 \mathrm{~A} / \mathrm{cm}^{2}$ can be achieved with 50000 p.p.m. $\mathrm{CO}$ at $423 \mathrm{~K}$ for the PBI-based PEFC whereas 25 p.p.m. is sufficient to cause polarization at $<0.8 \mathrm{~A} / \mathrm{cm}^{2}$ for the PFSAbased PEFC [17]. However, there are still open questions regarding sustainable long-term performance at higher temperatures, a critical issue.

The discussions in this work focus on modelling multi-species transport in the membrane region, which follows the previous work based on modelling multi-species transport in the gas channels and diffusion layers [18]. Transport in the membrane region is critical to a better understanding of the water distribution and the effects of crossover and contamination occurring through the membrane. The existing transport models in the literature are discussed and the most significant modelling philosophies for transport in fuel cells are identified. Using fundamental theory, a multi-species general transport equation is developed and its consistency with published theory is shown. This demonstrates a bridged gap between the different transport equations in the literature. The general transport equation presented in this work is applicable universally to both PFSA and PBI-based PEFCs; simulated results are presented using more widely available closure relations for lower temperature PEFCs from literature.

Three common modelling groups are acknowledged and classified according to the transport equation for the membrane region. First, models based on the use of the Nernst-Planck equation are used to describe the transport of hydrogen ions in the membrane. At present, it suffices to mention that this equation describes the flux of a single species due to migration, diffusion, and convection. An early example of this was in the model of Ridge et al. [19], although they excluded convective fluxes. The most significant use of the NernstPlanck equation was made by Bernardi and Verbrugge (BV) a few years later $[\mathbf{1 5}, \mathbf{2 0}]$. Bernardi first presented a relatively simple study identifying the required operating conditions to achieve water balance $[21]$. Following work first focused on a onedimensional half-cell model comprising of cathode diffuser, catalyst layer and membrane layer [20], and then extended to a complete one-dimensional fuel cell model [15]. They also made use of the Nernst-Planck equation to model dissolved hydrogen and oxygen transport in the membrane region, and considered the effects of applying back pressure on the cathode side to maintain water balance. Parallel two-phase flow was also considered, with the liquid-phase velocity in the membrane pores defined 
using Schlogl's velocity equation. In their work, however, they consider the membrane to be thin and assume it to be uniformly hydrated. In reality, competing water transport mechanisms would cause non-uniformity in the water distribution across the membrane region, limiting the applicability of this type of model. Cross-interactions between species are also neglected, when using the Nernst-Planck equation. Incorporation of structural parameters, however, allowed their model to make significant predictions; they found that reactions across the cathode catalyst layer were unlikely to be uniform, implying that cost-savings were possible by concentrating catalyst material closer towards the cathode gas diffuser.

The Nernst-Planck approach has been adopted by Pisani et al. [22-24]. Initially, they adopted the BV model and successfully improved the model predictions at higher current densities [22]; the initial BV models did not predict well the polarizations at higher current densities caused by cathode flooding. Later work used the improved BV model to analyse the effect of the porous structure of the catalyst layer on cell performance [23], and later work focused on optimizing the BV model for faster computation by eliminating non-linear terms [24].

The NP-based BV models have also been adopted by Djilali et al. $[\mathbf{2 5}, \mathbf{2 6}$. They developed the model to include the effects of heat transfer and included Knudsen diffusion in the electrodes [25]. This research group then used the BV model to conduct a three-dimensional computational analysis of a section of the PEFC. Their model and other such models allowed the effects of geometric parameters of the gas diffusion layer on the cell performance [26] to be quantified.

The publication of the half-cell BV model [20] coincided with the publication of another significant model presented by Springer et al. [27]. The NernstPlanck equation is a derivative of dilute solution theory (DST). Another form of DST was used by Springer et al. [27] who used the equation to describe in part the transport of water across the membrane, assuming that the gradient in chemical potential of water drives a diffusive flux of water across the membrane from cathode to anode. The commonality between the Nernst-Planck-based BV models and the Springer et al. type models is the fact that both their key transport equations belong to DST. The difference is they both use the derivatives of DST to model the transport of different primary species; hydrogen ions for BV and water for Springer et al. [27]. Springer et al. modify the DST equation such that the gradient in the chemical potential of water is translated into a gradient in water content per membrane charge site, $\lambda$. The other significant difference is the explicit inclusion of electro-osmotic water drag; an extra term is appended to account for the drag of water by hydrogen ions across the membrane from anode to cathode. The net result is a counter-directional flux of dragged water and diffusing water in the membrane, setting up a non-uniform water distribution across the membrane thickness. This forms the basis of many 'diffusion' models.

In 1993, Van Nguyen and White adopted this approach to model heat and mass transfer in twodimension [28], acknowledging the counter-directional diffusive and drag fluxes of water across the membrane in one-dimension. They found that the back diffusion of water across the cell from cathode to anode was insufficient to keep the membrane well-humidified and therefore optimally conductive, and consequently concluded that anode humidification was necessary under certain operating conditions. Similar studies were conducted by Okada et al. [29]. In later work, the basic diffusion-based transport equation was modified to account for a pressure-driven convective water flux in the membrane [30]. By this point, the DST-derived diffusion term is reduced to Fick's law and the appended convective term is simply D'Arcy's law. The resulting transport equation can therefore be classed as being 'semi-composite'. Later modelling efforts by Van Nguyen et al. investigated the improvements in cell performance when interdigitated gas distributors were used to block-off direct inlet and exit paths for gases and to force flow though electrodes [31]. Following work focused more on improving the modelling of liquid water and considering saturation explicitly [32]. These studies of Van Nguyen et al. have directly influenced cell design by identifying the regions of the cell where flooding is most likely to occur first.

The water diffusion and drag-based transport equation based on DST have commonly formed the basis of transient models [33-35]. Recent applications have attempted to address again the issues of thermal and water management [36]. The 'semicomposite' approach has also been widely used in the literature [37-41]. Kulikovsky [38], in particular, considered the non-linear diffusion of water in the membrane, leading to the identification of co-existing dry and wet regions. More recent work has been orientated around determining cell performance under co- and counter-flow configurations with two-phase water, acknowledging counter-flow configurations allow for better internal humidification under certain conditions $[\mathbf{3 9}, \mathbf{4 0}]$.

A few years following the publication of the BV $[\mathbf{1 5}, \mathbf{2 0}, 21]$ and Springer et al. [27] models, Fuller and Newman presented an alternative model that used concentrated solution theory (CST) to describe transport in the membrane [42]. This was based 
upon earlier work, where it was illustrated that a multi-component form of CST could be used to describe the transport of a three-species system: water, hydrogen ions, and electrolyte membrane [43]. Their model assumed temperature to change along the length of the gas channel, and illustrated that the rate of heat removal from the cell was critical in preventing membrane dehydration. A key aspect of their work was the application of CST to simultaneously model the transport of multiple species without decomposing the transport equation into independent constituents, as done by the DST treatments of BV $[\mathbf{1 5}, \mathbf{2 0}]$, Springer et al. [27] and their derivatives. Also, they illustrated that it was possible to model the membrane system without making the assumption that the system is dilute.

The application of CST for FC modelling has been developed over several lines. Janssen [44] used CST to model the effect of two-phase water transport in the electrodes on the electro-osmotic drag coefficient in the membrane. More recently, two-phase water transport in the membrane was modelled by Weber and Newman, accounting for both liquid and vapour phase water boundary conditions for the membrane $[\mathbf{1 6}, \mathbf{4 5}, \mathbf{4 6}]$. In both the work of Janssen [44] and Weber and Newman [16, 45, 46], the expansion of the key transport equations yields frictional coefficients, which account for interactions between species. These coefficients are related to waterphase-dependant transport properties such as the electro-osmotic drag coefficient. Although proving useful to predict the water flux in the membrane under two-phase conditions, the models are not able to predict $\mathrm{H}_{2}$ or oxygen crossover using CST without resorting to Fick's Law. Indeed, Weber and Newman [16] illustrated that Fick's law would be superimposed on to the CST-based two-phase water flux equations to define $\mathrm{H}_{2}$ and $\mathrm{O}_{2}$ penetration in the membrane. This eludes the utility of the multicomponent nature of CST. Meyers and Newman $[47,48,49]$, however, maintained the multi-component nature of CST to model the direct methanol fuel cell (DMFC), for which fuel crossover is a significant issue.

Other studies have also made use of CST. Wohr et al. [50] used it to develop a dynamic model with energy balance. They suggested several ways to improve membrane humidity as a result, including raising humidifier temperature, increasing diffuser porosity and reducing diffuser thickness, and finally suggested the use of cooling plates to improve heat removal. Futerko and Hsing applied forms of CST to model water transport in the membrane, focusing more on two-dimensional effects $[\mathbf{5 1}, \mathbf{5 2}]$. They considered the effect of humidity on membrane resistance $[\mathbf{5 1}]$, and operation without reactant feed humidification [52]. Thampan et al. [53] developed a model with a similar approach to Janssen [44] and Weber and Newman [16], concentrating on the conductivity of the membrane at different operating temperatures, when the membrane is in contact with water in either liquid or vapour phase.

Other significant models that do not strictly pertain to the categorizations above are mentioned here. Eikerling et al. [54] proposed a model on the basis of the assumption that water flux in the membrane was characterized by capillary pressureinduced convection and electro-osmotic drag. Key to their model was the use of pore-size distribution data to determine local conductivity and permeability. Meier et al. [55] also used the capillary pressure argument to propose a convective flux of water in the membrane and attributed it to causing the non-uniform distribution of water across the membrane. Both these models make use of D'Arcys law to describe the convective water flux. Baschuk and Li [56] proposed a BV-based model that was more orientated to defining equivalent resistances throughout the thickness of the cell. Finally, there is semi-empirical-based models of Amphlett et al. $[\mathbf{5 7}, \mathbf{5 8}]$. In these models, the activation and ohmic overvoltages are defined initially in a theoretical basis, with characteristic constants grouped and defined using experimental data. These models focus squarely on producing performance curves and exhibit generally good correlation with experimental data These such models provide quick cell performance predictions without detailed consideration given to cell-level transport phenomenon.

The above is by no means an exhaustive list of modelling efforts, but aims to identify the Nernst-Planck-based BV $[\mathbf{1 5}, \mathbf{2 0}]$ approach, the diffusion-based approach of Springer et al. [27] and the CST-based approach of Newman et al. $[16,42,43,45-49]$. Further discussions into modelling approaches is given by Weber and Newman [59] and Wang [60].

The purpose of this work is to illustrate that all these three prominent modelling approaches can be related by a multi-species (general) transport equation. A general transport equation is thus derived and its validity is demonstrated by deriving all three key transport equations in the literature (dilute solution-based Nernst-Planck, dilute solution-based diffusion equation and CST). The general transport equation is then applied to a simple PEFC model. Calculated water content curves obtained using the general transport equation are then compared with published data. Finally, the multi-species facet of the model is used to predict $\mathrm{H} 2$ crossover in the membrane. 


\section{THEORETICAL STUDY}

\subsection{Driving force equation}

The common form of CST can be traced back to the work of Hirschfelder et al. [61]. The total driving force of a general species $i$ was defined as

$$
d_{i}=\frac{n_{i} m_{i}}{n_{\mathrm{T}} k T}\left[\Lambda_{i}-\frac{1}{\rho} \nabla p+\frac{1}{\rho} \sum_{j} n_{j} X_{j}\right]
$$

where $n_{i}$ is the molecular concentration of species $i$ (molecules $/ \mathrm{cm}^{3}$ ), $m_{i}$ is the molecular mass of species $i$ (g/molecule), $n_{\mathrm{T}}$ is the total molecular concentration (molecules $/ \mathrm{cm}^{3}$ ) $k$ is the Boltzman constant $(\mathrm{J} / \mathrm{K}), T$ is the local temperature $(\mathrm{K}), \rho$ is the total density $\left(\mathrm{g} / \mathrm{cm}^{3}\right), \Lambda_{i}$ is the diffusive flux affinity $(\mathrm{J} / \mathrm{g} \mathrm{cm})$ and $\boldsymbol{X}_{j}$ is the general molecular force acting on species $j$ (J/cm molecule).

The first term in the bracket of equation (1) reflects the flux due to diffusion; the second reflects convective flux due to a gradient in total pressure; the final term reflects the interactive flux that is induced because of external fields acting upon the other species in the multi-species system.

Hirschfelder et al. [61] suggested that there are three physical contributors to the diffusive flux of a general species $i$; a gradient in electrochemical potential; a gradient in temperature and an additional general flux caused by an external field

$$
\Lambda_{i}=\frac{1}{m_{i}} \nabla \boldsymbol{\mu}_{i}+\frac{\overline{\boldsymbol{S}}_{i}}{m_{i}} \nabla T-\frac{1}{m_{i}} \boldsymbol{X}_{i}
$$

where $\nabla \boldsymbol{\mu}_{i}$ is the gradient in molecular electrochemical potential of the general species $i(J /$ molecule) and $\bar{S}_{i}$ is the molecular entropy of the general species $i$ (J/molecule K).

Substituting equation (2) into equation (1) yields

$$
\begin{aligned}
d_{i}= & \frac{n_{i}}{n_{\mathrm{T}} k T}\left[\nabla \boldsymbol{\mu}_{i}+\overline{\boldsymbol{S}}_{i} \nabla T-\frac{m_{i}}{\rho} \nabla p\right. \\
& \left.-\left(\boldsymbol{X}_{i}-\frac{m_{i}}{\rho} \sum_{j=1}^{\nu} n_{j} \boldsymbol{X}_{j}\right)\right]
\end{aligned}
$$

The molecular concentration of a general species $i$ is defined as $n_{i}=N_{\mathrm{A}} c_{i}$ where $c_{i}$ is the molar concentration $\left(\mathrm{mol} / \mathrm{cm}^{3}\right)$, and $N_{\mathrm{A}}$ is the number of molecules per mol of substance, i.e. the Avagadro Number (molecules $/ \mathrm{mol}$ ). The total molar concentration is defined as $c_{\mathrm{T}}=n_{\mathrm{T}} / N_{\mathrm{A}}$ and the definition of the Boltzmann constant is $k=R / N_{\mathrm{A}}$ where $R$ is the universal gas constant $(\mathrm{J} / \mathrm{mol} \mathrm{K})$

As the above treatment considers particle-level properties, it is recast into more convenient molar terms by using the Avagadro number. Substitution of these definitions into equation (3) gives the total driving force term for a general species $i$

$$
\begin{aligned}
d_{i}= & \frac{c_{i}}{c_{\mathrm{T}}} \frac{1}{R T} \\
& \times\left[\nabla \mu_{i}+\overline{\boldsymbol{S}}_{i} \nabla T-\frac{M_{i}}{\rho} \nabla p-\left(X_{i}-\frac{M_{i}}{\rho} \sum_{j=1}^{v} c_{j} X_{j}\right)\right]
\end{aligned}
$$

This is the general driving force equation and accounts for the physical conditions that drive overall intermolecular transport including effects due to the following.

1. A gradient in electrochemical potential, composed of:

(a) a gradient in concentration,

(b) a gradient in electric potential.

2. An overall temperature gradient.

3. A gradient in total pressure.

4. A force induced by an external field.

\subsection{Molecular and thermal diffusion equation}

From the same work of Hirshfelder et al. [61], it is possible to define the general driving force as being the sum of the forces driving molecular diffusion and thermal diffusion

$$
\begin{aligned}
d_{i}= & \sum_{j} \frac{n_{i} n_{j}}{n_{\mathrm{T}}^{2} D_{i j}}\left(v_{j}-v_{i}\right) \\
& +\nabla \ln T \sum_{j} \frac{n_{i} n_{j}}{n_{\mathrm{T}}^{2} D_{i j}}\left(\frac{D_{j}^{\mathrm{T}}}{n_{j} m_{j}}-\frac{D_{i}^{\mathrm{T}}}{n_{i} m_{i}}\right)
\end{aligned}
$$

where $D_{i j}$ is the diffusion coefficient of species $i$ in species $j\left(\mathrm{~cm}^{2} / \mathrm{s}\right), v_{i}$ is the velocity of species $i$ $(\mathrm{cm} / \mathrm{s})$, and $D_{i}^{\mathrm{T}}$ is the thermal diffusion coefficient of species $i\left(\mathrm{~cm}^{2} / \mathrm{s}\right)$.

Equation (5) is shifted from molecular values to molar values using $n_{i} m_{i}=\rho_{i}$ and $n_{i}=N_{\mathrm{A}} c_{i}$, giving

$$
d_{i}=\sum_{j} \frac{c_{i} c_{j}}{c_{\mathrm{T}}^{2} D_{i j}}\left[v_{j}-v_{i}+\left(\frac{D_{j}^{\mathrm{T}}}{\rho_{j}}-\frac{D_{i}^{\mathrm{T}}}{\rho_{i}}\right) \nabla \ln T\right]
$$

\subsection{General transport equation}

Equation (4) describes the physical conditions that induce molecular transport and equation (6) reflects the transport that occurs due to the physical drivers. Equating the two equations gives the general 
transport equation for concentrated solutions

$$
\begin{array}{r}
c_{i}\left[\nabla \mu_{i}+\overline{\boldsymbol{S}}_{i} \nabla T-\frac{M_{i}}{\rho} \nabla p-\left(\boldsymbol{X}_{i}-\frac{M_{i}}{\rho} \sum_{j \neq i}^{v} c_{j} X_{j}\right)\right] \\
\quad=R T \sum_{j} \frac{c_{i} c_{j}}{c_{\mathrm{T}} D_{i j}}\left[v_{j}-v_{i}+\left(\frac{D_{j}^{\mathrm{T}}}{\rho_{j}}-\frac{D_{i}^{\mathrm{T}}}{\rho_{i}}\right) \nabla \ln T\right]
\end{array}
$$

A species with zero valence can be affected by an external field, for example, a field in electric potential set up by an electric current can cause a species with zero valence to be electro-osmotically dragged, due to the flux of hydrogen ions.

The molar flux of a species $\dot{i}, \dot{n}_{i}\left(\mathrm{~mol} / \mathrm{cm}^{2} \mathrm{~s}\right)$ is defined as $\dot{n}_{i}=v_{i} c_{i}$. When $\nabla P=\nabla T=0$, substituting into and rearranging equation (7) yields

$$
\dot{n}_{i}=-\frac{c_{\mathrm{T}}}{c_{j}} \frac{D_{i j}}{R T} c_{i} \nabla \mu_{i}+\frac{c_{\mathrm{T}}}{c_{j}} \frac{D_{i j}}{R T} c_{i}\left(X_{i}-\frac{M_{i}}{\rho} c_{j} X_{j}\right)+c_{i} v_{j}
$$

The first and last terms on the right hand side define diffusion and convection. The middle term is related to electro-osmotic drag flux. When considering the flux of water (species $i$ ) in the membrane (species $j$ ) where the membrane species experiences no drag, the electro-osmotic drag flux of water equates to

$$
\dot{n}_{\mathrm{w}, \mathrm{drag}}=\frac{c_{\mathrm{w}}}{c_{\mathrm{m}}} \frac{c_{\mathrm{T}}}{R T} D_{\mathrm{w}, \mathrm{m}} X_{\mathrm{w}}
$$

The electro-osmotic drag ratio $\xi_{i}$ is now introduced, which is the number of molecules of species $i$ dragged per hydrogen ion, that is

$$
\xi_{i}=\frac{n_{i, \mathrm{drag}}}{n_{\mathrm{H}+}}=\frac{c_{i, \mathrm{drag}}}{c_{\mathrm{H}+}}
$$

As the velocity with which water is dragged is equal to the velocity of hydrogen ions, i.e. $v_{\mathrm{w}, \mathrm{drag}}=v_{\mathrm{H}+}$, this gives

$$
\begin{gathered}
\xi_{i}=\frac{\dot{n}_{i, \mathrm{drag}}}{\dot{n}_{\mathrm{H}+}} \\
\xi_{\mathrm{w}}=\frac{\dot{n}_{\mathrm{w}, \mathrm{drag}}}{\dot{n}_{\mathrm{H}+}}
\end{gathered}
$$

Substitution of equation 11(a) and (b) into equation (9) and rearranging provides the general molar force in relation to the electro-osmotic drag ratio of any species $i$ and of water as

$$
\begin{aligned}
X_{i} & =\xi_{i} \dot{n}_{\mathrm{H}+} \frac{R T}{D_{i, \mathrm{~m}}} \frac{c_{\mathrm{m}}}{c_{\mathrm{T}} c_{i}} \\
X_{\mathrm{w}} & =\xi_{\mathrm{w}} \dot{n}_{\mathrm{H}}+\frac{R T}{D_{\mathrm{w}, \mathrm{m}}} \frac{c_{\mathrm{m}}}{c_{\mathrm{T}} c_{\mathrm{w}}}
\end{aligned}
$$

Generally, equation 12 (a) can be applied equally to a multi-species concentrated system because of the following reasons.

1. It is derived from a general concentrated solution system.

2. The purely electro-osmotic drag characteristics of species ' $i$ ' alone in the membrane is dependant only upon its transport properties in the membrane (accounted for by $D_{i, \mathrm{~m}}$ ) and the magnitude of the hydrogen ion flux (accounted for by $\dot{n}_{\mathrm{H}+}$ ). The overall electro-osmotic drag-induced flux for a species ' $i$ ' including interactions with other electro-osmotically dragged species is accounted for by $M_{i} / \rho \sum_{j \neq i} c_{j} X_{j}$ in equation (7).

3. Electro-osmotic drag is assumed to occur independently of temperature and pressure gradients.

Using the derived expression for $X_{i}$, the general transport equation, equation (7), for concentrated solutions becomes

$$
\begin{aligned}
c_{i}\left[\nabla \mu_{i}\right. & \left.+\bar{S}_{i} \nabla T-\frac{M_{i}}{\rho} \nabla p\right] \\
= & R T \sum_{j} \frac{c_{i} c_{j}}{c_{\mathrm{T}} D_{i j}}\left[v_{j}-v_{i}+\left(\frac{D_{j}^{\mathrm{T}}}{\rho_{j}}-\frac{D_{i}^{\mathrm{T}}}{\rho_{i}}\right) \nabla \ln T\right] \\
& +R T \dot{n}_{\mathrm{H}+\frac{c_{\mathrm{m}}}{c_{\mathrm{T}}}}\left(\frac{\xi_{i}}{D_{i, \mathrm{~m}}}-\frac{\rho_{i}}{\rho} \sum_{j \neq i, \mathrm{mem}}^{v} \frac{\xi_{j}}{D_{j, \mathrm{~m}}}\right)
\end{aligned}
$$

\section{THEORETICAL VALIDATION}

In both key dilute solution models $[\mathbf{1 5}, \mathbf{2 0}, \mathbf{2 7}]$ and key concentrated solution model [43], one-dimensional temperature effects across the cell were neglected $(\nabla T=0)$. Also, none of these explicitly consider the effect of the overall pressure gradient $(\nabla p=0)$. This leaves the general transport equation in a simpler form

$$
\begin{aligned}
c_{i} \nabla \mu_{i}= & R T \sum_{j} \frac{c_{i} c_{j}}{c_{\mathrm{T}} D_{i j}}\left[v_{j}-v_{i}\right] \\
& +R T \dot{n}_{\mathrm{H}+} \frac{c_{\mathrm{m}}}{c_{\mathrm{T}}}\left(\frac{\xi_{i}}{D_{i, \mathrm{~m}}}-\frac{\rho_{i}}{\rho} \sum_{j \neq 1, \mathrm{mem}}^{v} \frac{\xi_{j}}{D_{j, \mathrm{~m}}}\right)
\end{aligned}
$$




\subsection{Dilute solutions}

Fundamentally, for a dilute solution, the concentration of a general minor solute species $i$ is assumed to be significantly lower than that of the solvent species $j, c_{i} \ll c_{j}$, and $c_{j} \approx c_{\mathrm{T}}$. Also, the solvent species experiences no drag, hence $\xi_{j}=0$. Substituting these conditions into the equation (14) reduces the general transport equation to the following for the solute species $i$

$$
\dot{n}_{i}=-\frac{D_{i, j}}{R T} c_{i} \nabla \mu_{i}+\xi_{i} \dot{n}_{\mathrm{H}+}+v_{j}
$$

This is the key transport equation for dilute solutions, which includes flux due to electro-osmotic drag.

\subsection{Model of Springer et al.}

Springer et al. [27] consider the transport of water (solute species $i$ ) in the electrolyte membrane (solvent species $j$ ). As the electrolytic membrane is static, $v_{\mathrm{m}}=0$ and the general transport equation (15) can be rearranged to yield the net water flux across the membrane

$$
\dot{n}_{\mathrm{w}}=\frac{D_{\mathrm{w}, \mathrm{m}}}{R T} c_{\mathrm{w}} \nabla \mu_{\mathrm{w}}+\xi_{\mathrm{w}} \dot{n}_{\mathrm{H}+}
$$

where the first term on the right hand side describes diffusive flux and is consistent with equation (19), which appears in the work of Springer et al. [27]. The second term describes electro-osmotic drag flux and is consistent with equation (18) in the same work.

\subsection{Model of BV}

In the BV models $[\mathbf{1 5}, \mathbf{2 0}]$, the key transport equation is the Nernst-Planck equation, which is applied to describe the transport of dissolved hydrogen ions (solute species $i$ ) in a bulk system consisting of water and electrolytic membrane (solvent species pair $j$ ) where $\xi_{i}=0$. The electrochemical potential of a species is defined as [62]

$$
\nabla \mu_{i}=R T \frac{\nabla c_{i}}{c_{i}}+z_{i} F \nabla \phi
$$

where $F$ is the Faraday constant ( $C$ /equiv.), $z_{i}$ is the valence of species $i$, and $\nabla \phi$ is the gradient in electric potential $(\mathrm{V} / \mathrm{cm})$. Substitution into the dilute solution transport equation (15) yields the familiar Nernst-Planck equation

$$
\dot{n}_{i}=-\frac{D_{i, j}}{R T} z_{i} F c_{i} \nabla \phi-D_{i, j} \nabla c_{i}+v_{j}
$$

where $v_{j}$ becomes the pore-water velocity in the membrane, defined using Schlogl's velocity equation

$$
v_{j}=\frac{k_{\phi}}{\mu} z_{j} c_{j} F \nabla \phi-\frac{k_{\mathrm{p}}}{\mu} \nabla p
$$

Here, $k_{\phi}$ and $k_{\mathrm{p}}$ are the electrokinetic and hydraulic permeabilities, respectively, $\left(\mathrm{cm}^{2}\right)$ and $\mu$ the viscosity $(\mathrm{g} / \mathrm{cm} \mathrm{s})$, not to be confused with the electrochemical potential, and $\nabla p$ specifically the hydraulic pressure gradient.

\subsection{Concentrated solutions}

Newman [62] stated that, for a three-species system, it is more rigorous to use CST to describe transport. In the treatment of Weber and Newman [16], electro-osmotic drag is implicitly absorbed into frictional coefficients, which are related to the diffusion coefficients $D_{i j}$. Because of this treatment, which is based upon assumptions of marginal currents and marginal chemical potential gradients for water through the membrane, the explicit electro-osmotic drag terms in equation (14) reduce to zero $\xi=0$. Consequently, substitution into the general transport equation (14) leaves the common form of CST, which is comparable to the Stefan-Maxwell equation

$$
c_{i} \nabla \boldsymbol{\mu}_{i}=R T \sum_{j} \frac{c_{i} c_{j}}{c_{\mathrm{T}} D_{i j}}\left[v_{j}-v_{i}\right]
$$

\section{MODEL DEVELOPMENT}

\subsection{Governing equations}

The validity of the general transport equation given by equation (14) can be examined by applying it to model multi-species transport in one-dimension across the PEFC. This is done in the context of an isothermal and isobaric model. The electrode model is based on previous work on multi-species transport [18], but modified to give concentrations rather than mole fractions. For the same reason, equation (14) is applied in the electrodes where electro-osmotic drag does not occur (all species have zero valence) without deriving the Stefan-Maxwell equation. The assumptions of the new model are different to the previous model [18] in the following aspects.

1. The membrane region is characterized as a concentrated solution system with at least three constituent species; $\mathrm{H}_{2} \mathrm{O}$, electrolyte membrane, and $\mathrm{H}+$ ions.

2. The flux of any additional species can be treated as part of the concentrated solution system, 
without the need to superimpose an independent flux equation based on Fick's law.

3. The diffusion coefficient of $\mathrm{H}+$ in the concentrated solution system is characterized solely by its dissolution in water.

(a) Diffusivity in the dry membrane is zero, i.e. $D_{\mathrm{H}+\text {,mem }} \cong 0$.

(b) Diffusivity in the water contained in a humidified membrane is non-zero and given by $\mathrm{BV}$ [15] $D_{\mathrm{H}+, \mathrm{w}}=4.5 \times 10^{-5} \mathrm{~cm}^{2} / \mathrm{s}$.

4. For the four species system including $\mathrm{H}_{2}$, the diffusivity of $\mathrm{H}+$ in $\mathrm{H}_{2}$ in the membrane region is negligible, i.e. $D_{\mathrm{H}+\mathrm{H}_{2}} \cong 0$.

Capillary forces in the electrodes are assumed to be negligible for the current densities considered in this study where water is assumed to exist in vapour form [63].

A summary of the key equations for the channel, electrode, and membrane regions of the cell are given in Tables $1-3$, respectively. The conditions for the base case are given in Table 4. The base case reflects cell operation at $353 \mathrm{~K}$ where it is assumed that both air and $\mathrm{H}_{2}$ feeds are fully humidified to the same temperature, with three-species in the membrane system. The additional case given in Table 5 reflects a four-species concentrated solution system with the addition of hydrogen crossover. The $D_{i, \mathrm{~m}}$ diffusion coefficients should be regarded as the intra-diffusion coefficient of species $i$ in the membrane.

For the four-component system, it is assumed that hydrogen crossover leads to the formation of additional water at the cathode catalyst site. Such reaction would produce only heat energy, and not both heat and electrical energy. From a transport perspective, the magnitude of water and oxygen fluxes in the cathode increases, which in the model is reflected by changes in the cathode flux ratios $\alpha_{i}^{\mathrm{c}} ; \alpha_{\mathrm{w}}^{\mathrm{c}}=-2\left(1+\alpha_{\mathrm{w}}^{\mathrm{A}}+\alpha_{\mathrm{H}_{2}, \mathrm{X}}\right)$ and $\alpha_{o}^{\mathrm{c}}=1+\alpha_{\mathrm{H}_{2} \mathrm{X}}$. On a similar principal, the hydrogen flux in the anode increases $\alpha_{\mathrm{H}_{2}}^{\mathrm{A}}=1+\alpha_{\mathrm{H}_{2}, \mathrm{X}}$.

Table 1 Governing equations for channel model

\begin{tabular}{|c|c|c|}
\hline $\begin{array}{l}\text { Species flux in channel } \\
\left(\mathrm{mol} / \mathrm{cm}^{2} \mathrm{~s}\right)\end{array}$ & $\dot{n}_{i}^{\mathrm{E}-\mathrm{CH}}=\dot{n}_{i}^{\mathrm{E}-\mathrm{IN}}-\dot{n}_{i}^{\mathrm{E}-1}$ & {$[\mathbf{1 8}]$} \\
\hline $\begin{array}{l}\text { Species flux through } \\
\text { electrode }\left(\mathrm{mol} / \mathrm{cm}^{2} \mathrm{~s}\right)\end{array}$ & $\begin{aligned} \dot{n}_{i}^{\mathrm{E}} & =\alpha_{i}^{\mathrm{E}} \dot{n}_{n}^{\mathrm{E}} \\
& \text { anode: } \dot{n}_{\mathrm{H}}^{\mathrm{A}-1}=I \\
& \text { cathode: } \dot{n}_{O}^{\mathrm{C}-1}=I / 2\end{aligned}$ & [18] \\
\hline $\begin{array}{l}\text { Total channel flux } \\
\left(\mathrm{mol} / \mathrm{cm}^{2} \mathrm{~s}\right)\end{array}$ & $\dot{n}_{\mathrm{total}}^{\mathrm{E}-\mathrm{CH}}=\sum_{i=1}^{n} \dot{n}_{i}^{\mathrm{E}-\mathrm{CH}}$ & {$[18]$} \\
\hline Channel mole fraction (-) & $y_{i}^{\mathrm{E}-\mathrm{CH}}=\frac{n_{i}^{-}}{\dot{n}_{\text {total }}^{\mathrm{E}-\mathrm{CH}}}$ & {$[\mathbf{1 8}]$} \\
\hline $\begin{array}{l}\text { Channel concentration } \\
\left(\mathrm{mol} / \mathrm{cm}^{3}\right)\end{array}$ & $c_{i}^{\mathrm{E}-\mathrm{CH}}=\frac{p}{R T} y_{i}^{\mathrm{E}-\mathrm{CH}}$ & - \\
\hline
\end{tabular}

Table 2 Governing equations for electrode model

\begin{tabular}{llc}
\hline Transport equation & $c_{i} \nabla \mu_{i}=R T$ & Equation (14) \\
& $\times \sum_{j} \frac{1}{c_{\mathrm{T}} D_{i j}}\left[c_{i} \dot{n}_{j}-c_{j} \dot{n}_{i}\right]$ & \\
$\begin{array}{c}\text { Total concentration } \\
\left(\mathrm{mol} / \mathrm{cm}^{3}\right)\end{array}$ & $c_{\mathrm{T}}=\sum_{i} c_{i}$ & - \\
$\begin{array}{c}\text { Total pressure (Pa) } \\
\text { Pressure'diffusivity } \\
\text { product }\left(\mathrm{Pa}-\mathrm{cm}^{2} / \mathrm{s}\right)\end{array}$ & $p=c_{\mathrm{T}} R T$ & - \\
& $p D_{i j}=a\left(\frac{T}{T_{c, i j}}\right)^{b}\left(M_{i j}\right)^{-1 / 2}$ & {$[\mathbf{6 8}],[\mathbf{2 6}]$} \\
\hline
\end{tabular}

\subsection{Solution procedure}

Figure 1 illustrates the solution procedure applied to the overall model for the four-species concentrated solution system in the membrane region. The differential transport equations in the three regions of the cell are solved using a Runge-Kutta algorithm.

\section{RESULTS AND DISCUSSIONS}

\subsection{Model validation: 3-species concentrated system}

The validity of the multi-species universal transport equation can be tested by comparing simulated water content curves for a three-species concentrated solution to existing published results. Formation of water at the cathode sets up a concentration gradient across the membrane, allowing for molecular transport from cathode to anode. This is opposed by an electro-osmotic drag flux of water from anode to cathode. Because the electroosmotic drag flux is directly proportional to current density, the water content at lower current densities is much more uniform. This was illustrated by Springer et al. [27]. Although their treatment and simulation only considered the flux of water in a dilute solution, the multispecies model presented here for concentrated solutions should principally predict the same phenomenon.

Figure 2 shows simulated water content curves using equation (14) for the base condition at four different current densities. The model predicts a relatively uniform water distribution at $0.1 \mathrm{~A} / \mathrm{cm}^{2}$, with a linear fall in water content from 14 molecules per charge site to 11 molecules per charge site. At $0.8 \mathrm{~A} / \mathrm{cm}^{2}$, the water content profile becomes nonlinear. At this current density, the cathode has 14.8 water molecules per charge site, whereas the anode is much drier with less than three molecules per charge site.

The water content characteristics are generally consistent with the published results of Springer et al. [27]. The CST based approach of equation 
Table 3 Governing equations for membrane model

\begin{tabular}{|c|c|c|}
\hline Transport equation & $\begin{aligned} c_{i} \nabla \mu_{i}= & R T \sum_{j} \frac{c_{i} c_{j}}{c_{\mathrm{T}} D_{i j}}\left[v_{j}-v_{i}\right]+R T \dot{n}_{\mathrm{H}} \\
& +\frac{c_{\mathrm{m}}}{c_{\mathrm{T}}}\left(\frac{\xi_{i}}{D_{i, \mathrm{~m}}}-\frac{\rho_{i}}{\rho} \sum_{j \neq i, \mathrm{mem}}^{v} \frac{\xi_{j}}{D_{j, \mathrm{~m}}}\right)\end{aligned}$ & Equation (14) \\
\hline Molar volume $\left(\mathrm{cm}^{3} / \mathrm{mol}\right)$ & $V=V_{\mathrm{m}}+\lambda V_{\mathrm{w}}$ & {$[16]$} \\
\hline Total concentration $\left(\mathrm{mol} / \mathrm{cm}^{3}\right)$ & $c_{\mathrm{T}}=\frac{1}{V}+\sum_{i \neq \mathrm{w}, \mathrm{mem}} c_{i}$ & - \\
\hline $\begin{array}{l}\text { Partial molar volume of } \\
\text { dry membrane }\left(\mathrm{cm}^{3} / \mathrm{mol}\right)\end{array}$ & $V_{\mathrm{m}}=\frac{E W}{\rho_{\mathrm{m}, \mathrm{dry}}}$ & {$[16]$} \\
\hline Water content per charge site(-) & $\lambda=c_{\mathrm{w}} V_{\mathrm{m}}$ & - \\
\hline $\begin{array}{l}\text { Water volume fraction in } \\
\text { membrane }(-)\end{array}$ & $f_{v}=\frac{\lambda V_{\mathrm{w}}}{V_{\mathrm{m}}+\lambda V_{\mathrm{w}}}$ & {$[\mathbf{1 6}]$} \\
\hline Expanded membrane thickness $(\mu \mathrm{m})$ & $t_{\mathrm{m}}=t_{\mathrm{m}, \mathrm{dry}}\left(1+0.36 \times \frac{\lambda V_{\mathrm{w}}}{V_{\mathrm{m}}}\right)$ & {$[16]$} \\
\hline
\end{tabular}

(14) suggests larger gradients in water content than the dilution solution theory approach of equation (15) at higher current densities $\left(>0.2 \mathrm{~A} / \mathrm{cm}^{2}\right)$. The difference is due to the DST assumption that the concentration of any minor species is much less than that of the solute. As a consequence, a $c_{j} / c_{\mathrm{T}}$ factor is missing in equation (15) for dilute solutions and assumed to be unity whereas, for concentrated solutions, it would be less than unity. The effect is to reduce the dominance of $c_{i}$ in the context of equation (15), particularly at low water contents $(\lambda<6)$, thereby reducing the overall water content throughout the membrane at any position. Overall, Fig. 2 illustrates that the new approach correctly predicts the expected water content profiles at various current densities.

\section{$5.2 \quad \mathrm{H}_{2}$ crossover: 4-species system}

The use of thinner membranes in fuel cells allows for better performance, because the uniformity in water content is improved at all current densities. This owes to the shorter molecular transport path for water from cathode to anode and has the overall effect of increasing the proton conductivity of the membrane region $[\mathbf{2 7}, \mathbf{6 4}]$. With better internal humidification, the need to provide external humidification, especially through the anode side, is somewhat mitigated [65]. On the same principal, however, the much-reduced molecular transport path exacerbates the phenomenon of crossover across the membrane. Specifically, the crossover of $\mathrm{H}_{2}$ is a key issue in PEFCs, owing to its small molecular diameter. In general, such crossover can be impeded by using thicker membranes [66], but the

Table 4 Properties for base-case three-species $\left(\mathrm{H}_{2} \mathrm{O}\right.$, electrolyte membrane, $\left.\mathrm{H}+\right)$ concentrated solution membrane system

\begin{tabular}{|c|c|c|}
\hline $\begin{array}{l}\text { Temperature (anode saturation, } \\
\text { cathode saturation, cell) }(\mathrm{K})\end{array}$ & $T_{\AA}^{\mathrm{sat}}=T_{\mathrm{C}}^{\mathrm{sat}}=T_{\text {cell }}=353 \mathrm{~K}$ & {$[27]$} \\
\hline $\begin{array}{l}\text { Membrane equivalent } \\
\text { weight (mol/equiv) }\end{array}$ & $\mathrm{EW}=1155$ & [27] \\
\hline Dry membrane density $\left(\mathrm{g} / \mathrm{cm}^{3}\right)$ & $\rho_{\mathrm{m}, \mathrm{dry}}=1.98$ & {$[\mathbf{1 8}]$} \\
\hline \multirow[t]{3}{*}{ Diffusivities $\left(\mathrm{cm}^{2} / \mathrm{s}\right)$} & $\begin{aligned} D_{\mathrm{w}, \mathrm{mem}}= & 10^{-6} \exp \left[2416\left(\frac{1}{303}-\frac{1}{T}\right)\right] \\
& \times(2.563-0.33 \lambda+0.0264 \lambda\end{aligned}$ & [27] \\
\hline & $D_{\mathrm{w}, \mathrm{H}+}=4.5 \times 10^{-5}$ & {$[\mathbf{1 5}]$} \\
\hline & $D_{\mathrm{H}+, \text { mem }}=0$ & - \\
\hline \multirow[t]{3}{*}{ Electro-osmotic drag ratios (-) } & $\xi_{\mathrm{w}}=\frac{2.5}{22} \lambda$ & [27] \\
\hline & $\xi_{\mathrm{m}}=0$ & - \\
\hline & $\xi_{\mathrm{H}+}=0$ & - \\
\hline Dry membrane thickness $(\mu \mathrm{m})$ & $t_{\mathrm{m}}=175$ & [27] \\
\hline Temperature gradient $(\mathrm{K} / \mathrm{cm})$ & $\nabla T=0$ & - \\
\hline Applied pressure gradient $(\mathrm{Pa} / \mathrm{cm})$ & $\nabla p=0$ & - \\
\hline Channel pressures & $p^{\mathrm{A}-\mathrm{CH}}=p^{\mathrm{C}-\mathrm{CH}}=303.975 \mathrm{kPa}$ & [27] \\
\hline
\end{tabular}


Table 5 Additional properties for four-species $\left(\mathrm{H}_{2} \mathrm{O}\right.$, electrolyte membrane, $\mathrm{H}+, \mathrm{H}_{2}$ ) concentrated solution membrane system

\begin{tabular}{|c|c|c|}
\hline \multirow[t]{2}{*}{$\mathrm{H}_{2}$ diffusivities $\left(\mathrm{cm}^{2} / \mathrm{s}\right)$} & $\begin{aligned} D_{\mathrm{H}_{2}, \mathrm{~m}}= & \left(2.2 \times 10^{-11} f_{v}+2.9 \times 10^{-12}\right) \\
& \times \exp \left[\frac{21000}{R}\left(\frac{1}{303.15}-\frac{1}{T}\right)\right] \\
& \times 45.596 \times 10^{3}\end{aligned}$ & {$[16][27]$} \\
\hline & $\begin{array}{l}D_{\mathrm{H}_{2, \mathrm{w}}}=\frac{24.70 \times 10^{3}}{p}\left(\frac{T}{146.55}\right)^{2.334} \\
D_{\mathrm{H}_{2}, \mathrm{H}_{+}}=0\end{array}$ & - \\
\hline Electro-osmotic drag ratio (-) & $\xi_{\mathrm{H}_{2}}=0$ & - \\
\hline $\begin{array}{l}\text { Channel pressures (Fig. 3) } \\
\text { (Figs } 4 \text { and 5) }\end{array}$ & $\begin{array}{l}p^{\mathrm{A}-\mathrm{CH}}=p^{\mathrm{C}-\mathrm{CH}}=101.325 \mathrm{kPa} \\
p^{\mathrm{A}-\mathrm{CH}}=p^{\mathrm{C}-\mathrm{CH}}=303.975 \mathrm{kPa}\end{array}$ & {$[67]$} \\
\hline
\end{tabular}

converse increase in crossover for thinner membranes amounts to unutilized fuel and so reduces the overall cell efficiency. The unused fuel corresponds to an equivalent crossover current density, and the target for future FC vehicles for this is $5 \mathrm{~mA} / \mathrm{cm}^{2}$ or less at $1 \mathrm{~atm}[67]$.

To model the crossover in the membrane, the conditions of Table 5 were applied in addition to the base conditions of Table 4 to simulate a four-component concentrated solution system in the membrane

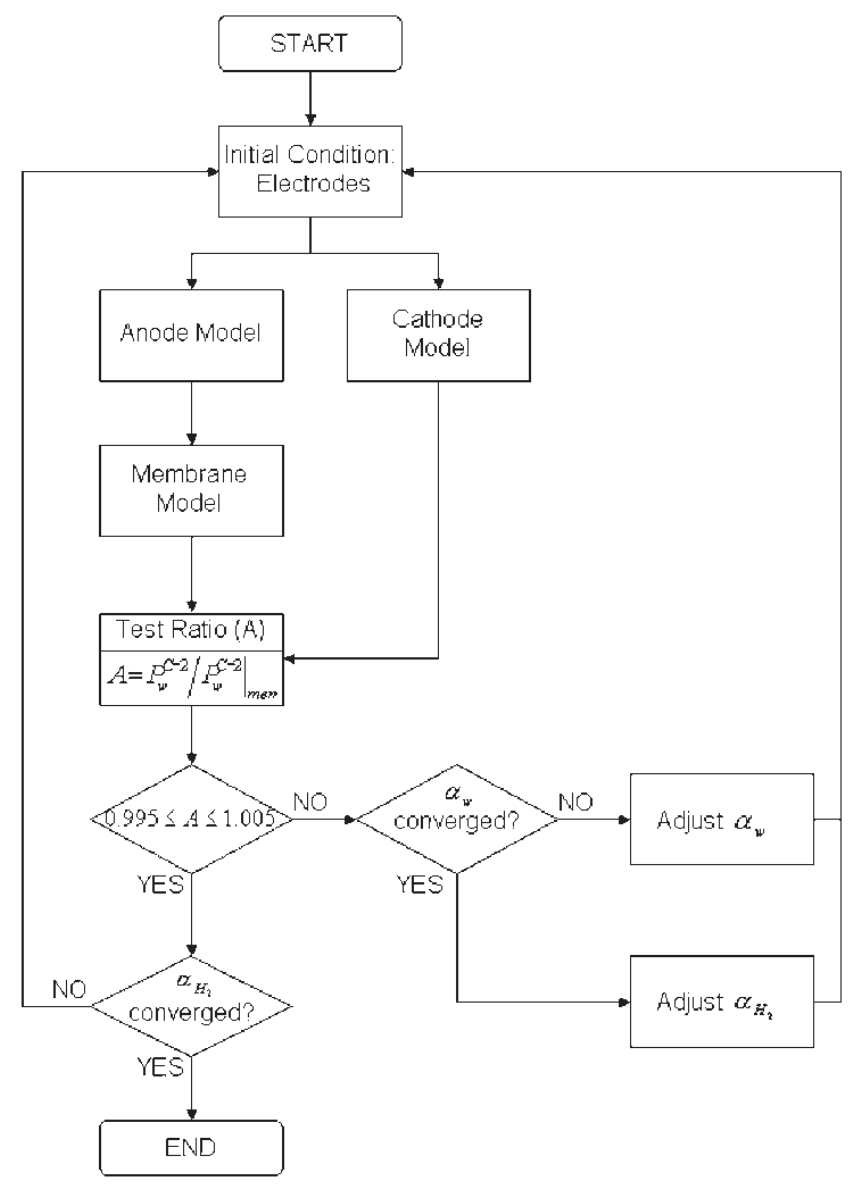

Fig. 1 Simulation flowchart region. Because there is no suitable data currently available in the literature, the electro-osmotic drag of $\mathrm{H}_{2}$ was assumed to be negligible.

Figures 3 and 4 show the relationship between membrane thickness and the net flux ratio of $\mathrm{H}_{2}$ across the membrane to oxidized $\mathrm{H}_{2}$ at $1 \mathrm{~A} / \mathrm{cm}^{2}$ for 353 and $383 \mathrm{~K} ; 1 \mathrm{~A} / \mathrm{cm}^{2}$ is chosen, because it is a typical operation point on the performance curve, and allows for easy translation into an equivalent current density $I_{\mathrm{X}}=\alpha_{\mathrm{H}_{2}-\mathrm{X}}^{\mathrm{A}} I, J_{\mathrm{X}}=2 F I_{\mathrm{X}}$, and $J=2 F I$. Hence $\alpha_{\mathrm{H}_{2}-\mathrm{X}}^{\mathrm{A}}$ should be 0.005 or less at $1 \mathrm{~A} / \mathrm{cm}^{2}$ when operated at $1 \mathrm{~atm}$.

Figure 3 considers the crossover for different thickness at $1 \mathrm{~atm}$. Large stacks $(\geq 10 \mathrm{~kW})$ are likely to operate at higher pressures, and this is considered in Figs 4 and 5. Figure 3 illustrates that the flux ratio drops below 0.005 (crossover current density of $5 \mathrm{~mA} / \mathrm{cm}^{2}$ ) for membranes thicker than around $30 \mu \mathrm{m}$. The flux ratio can be dropped further below $0.001\left(1 \mathrm{~mA} / \mathrm{cm}^{2}\right)$ for membranes thicker than $175 \mu \mathrm{m}$.

Figure 4 shows the crossover for different membrane thicknesses when the cell is operated at $3 \mathrm{~atm}$. For a cell operated at $353 \mathrm{~K}$, the results show that an increase in thickness from 25 to $50 \mu \mathrm{m}$ yields a 60 per cent drop in the net $\mathrm{H}_{2}$ crossover flux ratio, and is equivalent to a reduction in the crossover current density of $21.2 \mathrm{~mA} / \mathrm{cm}^{2}$. Increasing the thickness further by a factor of 3.5 from $50 \mu \mathrm{m}$ to $175 \mu \mathrm{m}$ yields a 72 per cent drop in the net $\mathrm{H}_{2}$ crossover flux ratio, but the magnitude of the drop in the crossover current density is less, at $10.3 \mathrm{~mA} / \mathrm{cm}^{2}$. The results also show that for the given base conditions, the crossover current density only drops below $5 \mathrm{~mA} / \mathrm{cm}^{2}$ above $150 \mu \mathrm{m}$ for operation at $353 \mathrm{~K}$.

Raising the operating temperature to $383 \mathrm{~K}$ at the same inlet pressures of $3 \mathrm{~atm}$ induces an increase in the crossover. The increase is relatively small for the thin $25 \mu \mathrm{m}$ membrane at 7 per cent and increases to 32 per cent for a $225 \mu \mathrm{m}$ membrane. The increase in the crossover with temperature can 


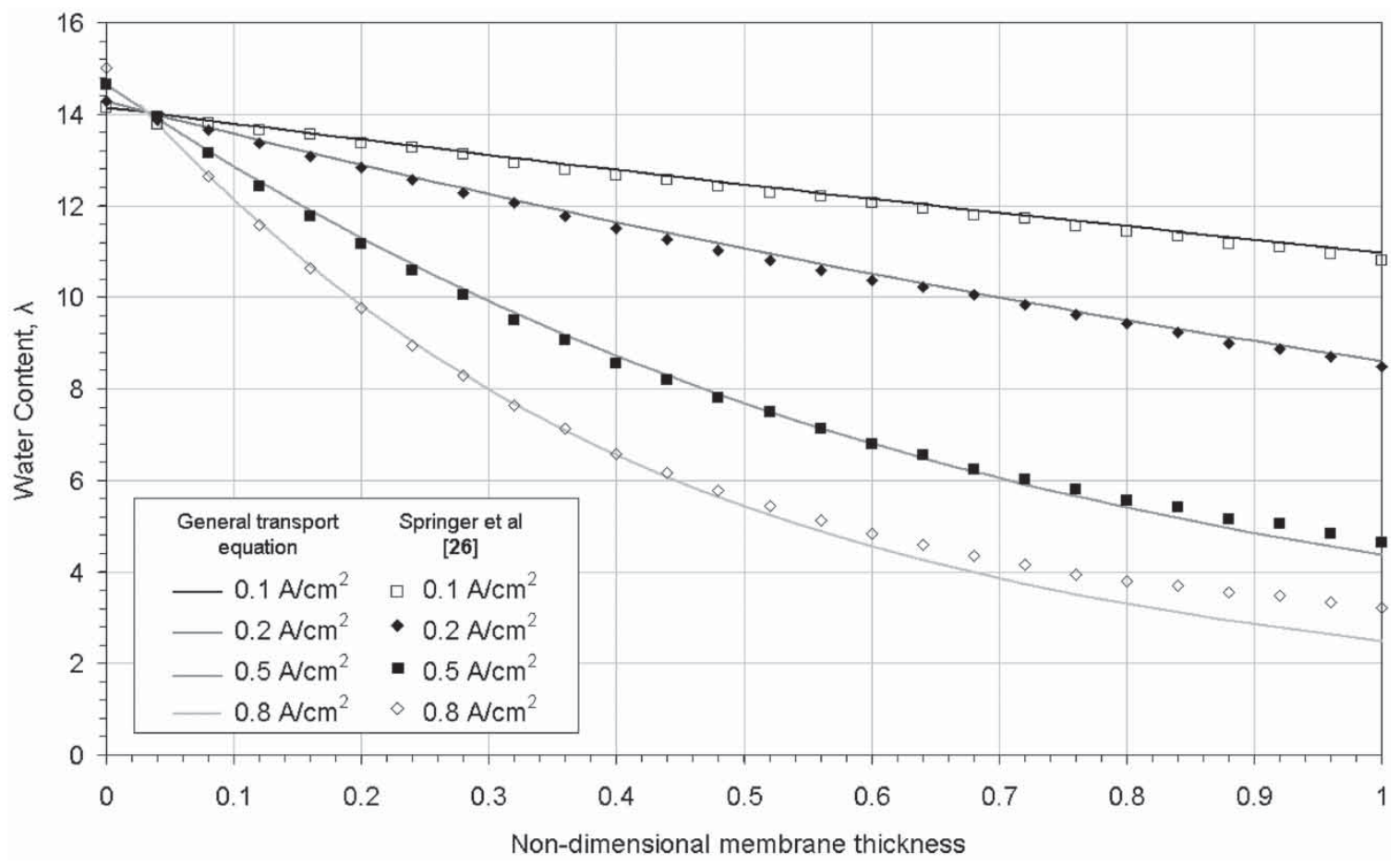

Fig. 2 Simulated membrane water content from the general transport equation, equation (14) and Springer et al. [27]

be attributed to the dependence of the hydrogen diffusion coefficient on temperature. When $f_{v}=0.5$ in the membrane region, $D_{\mathrm{H}_{2} \text {,mem }}$ increases from $2.07 \times 10^{-6} \mathrm{~cm}^{2} / \mathrm{s}$ at $353 \mathrm{~K}$ to $6.98 \times 10^{-5} \mathrm{~cm}^{2} / \mathrm{s}$ at $383 \mathrm{~K}$ and $D_{\mathrm{H}_{2} \mathrm{w}}$ increases from $0.641 \mathrm{~cm}^{2} / \mathrm{s}$ at $353 \mathrm{~K}$ to $0.776 \mathrm{~cm}^{2} / \mathrm{s}$ at $383 \mathrm{~K}$. Due to the increase in $\mathrm{H}_{2}$ crossover with temperature, the crossover current density only falls below $5 \mathrm{~mA} / \mathrm{cm}^{2}$, when the membrane is above $175 \mu \mathrm{m}$ thick.

Figure 5 considers the crossover at all practical current densities for three typical membrane thicknesses. In general, operation at low current densities

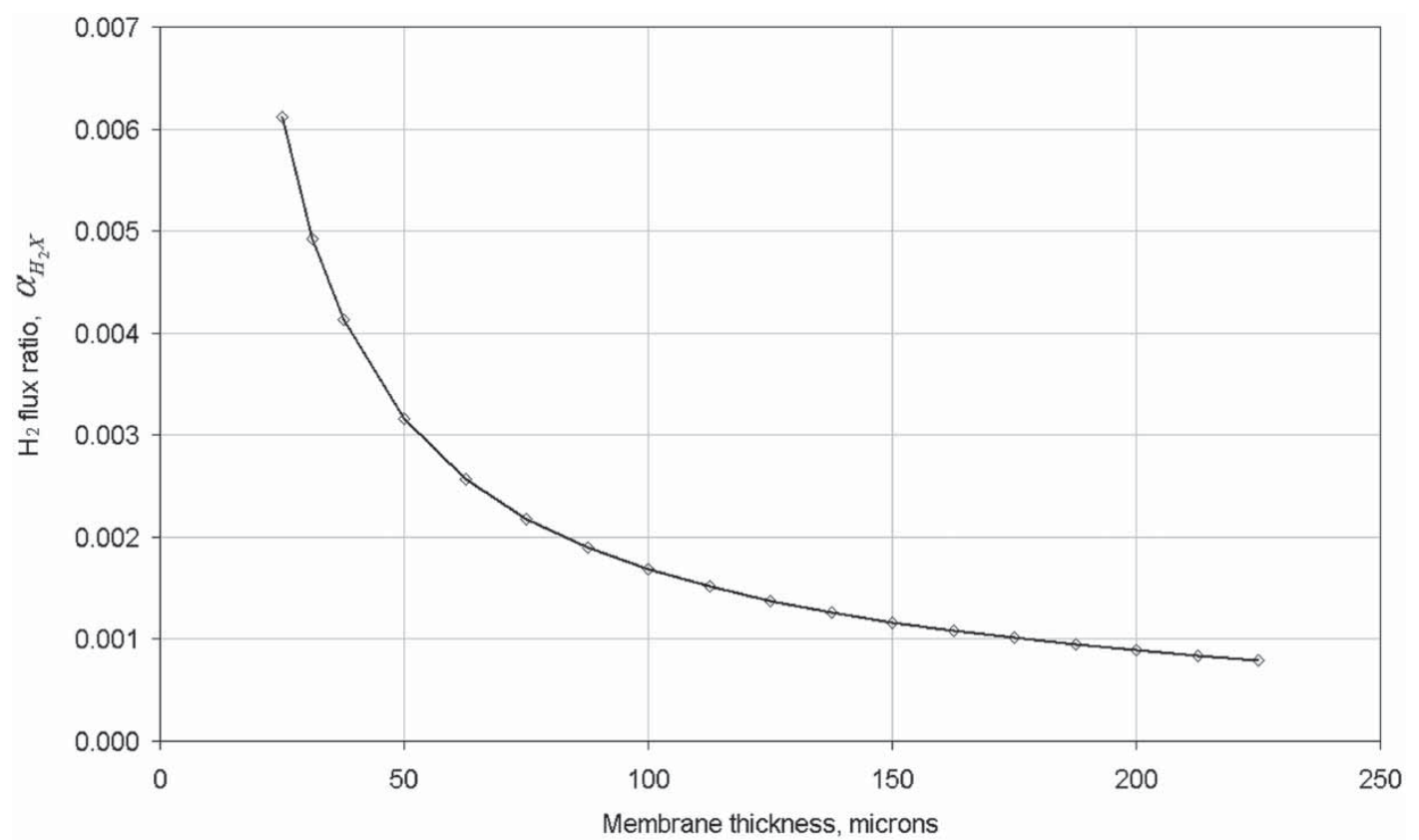

Fig. 3 H2 crossover dependence on dry membrane thickness at 1 atm 


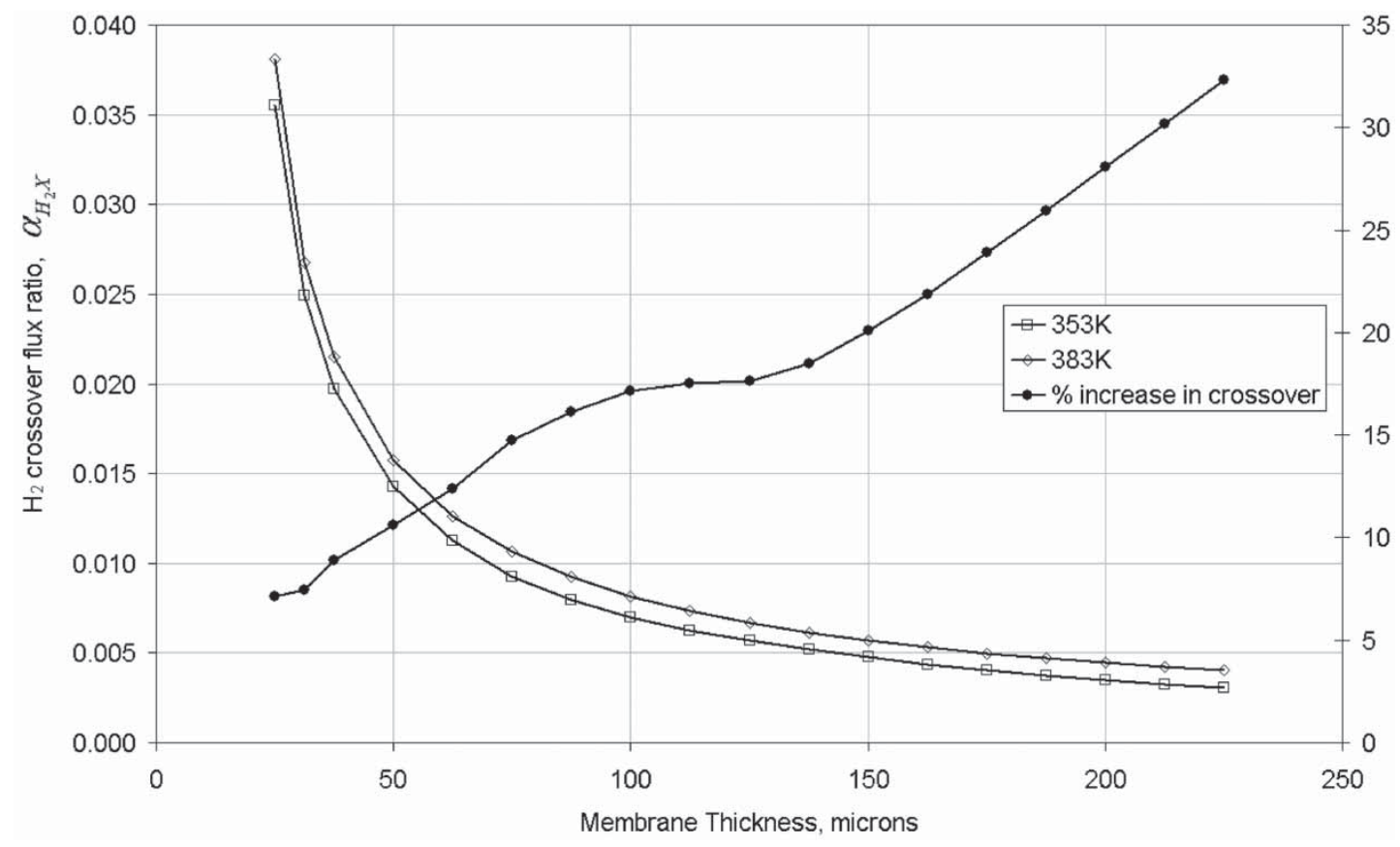

Fig. $4 \mathrm{H}_{2}$ crossover dependence on dry membrane thickness at $3 \mathrm{~atm}$

induces a high rate of $\mathrm{H}_{2}$ crossover. As current density increases, the crossover rate decays for all three membrane thicknesses considered. A similar phenomenon was observed previously for CO crossover through the membrane [18]. The thicker membranes exhibit consistently higher $\mathrm{H}_{2}$ crossover with respect to current density. The $\mathrm{H}_{2}$ flux ratio drops below 0.05 after $80 \mathrm{~mA} / \mathrm{cm}^{2}$ for the $175 \mu \mathrm{m}$ membrane, $150 \mathrm{~mA} / \mathrm{cm}^{2}$ for the $100 \mu \mathrm{m}$ membrane, and $300 \mathrm{~mA} / \mathrm{cm}^{2}$ for the $50 \mu \mathrm{m}$ membrane. At $1 \mathrm{~A} / \mathrm{cm}^{2}$, the $175 \mu \mathrm{m}$ membrane exhibits a reduction in the flux ratio below 0.005 . The $100 \mu \mathrm{m}$ membrane is still allowing a $\mathrm{H}_{2}$ crossover ratio of 0.007 and the $50 \mu \mathrm{m}$ membrane allows double than that at 0.014 .

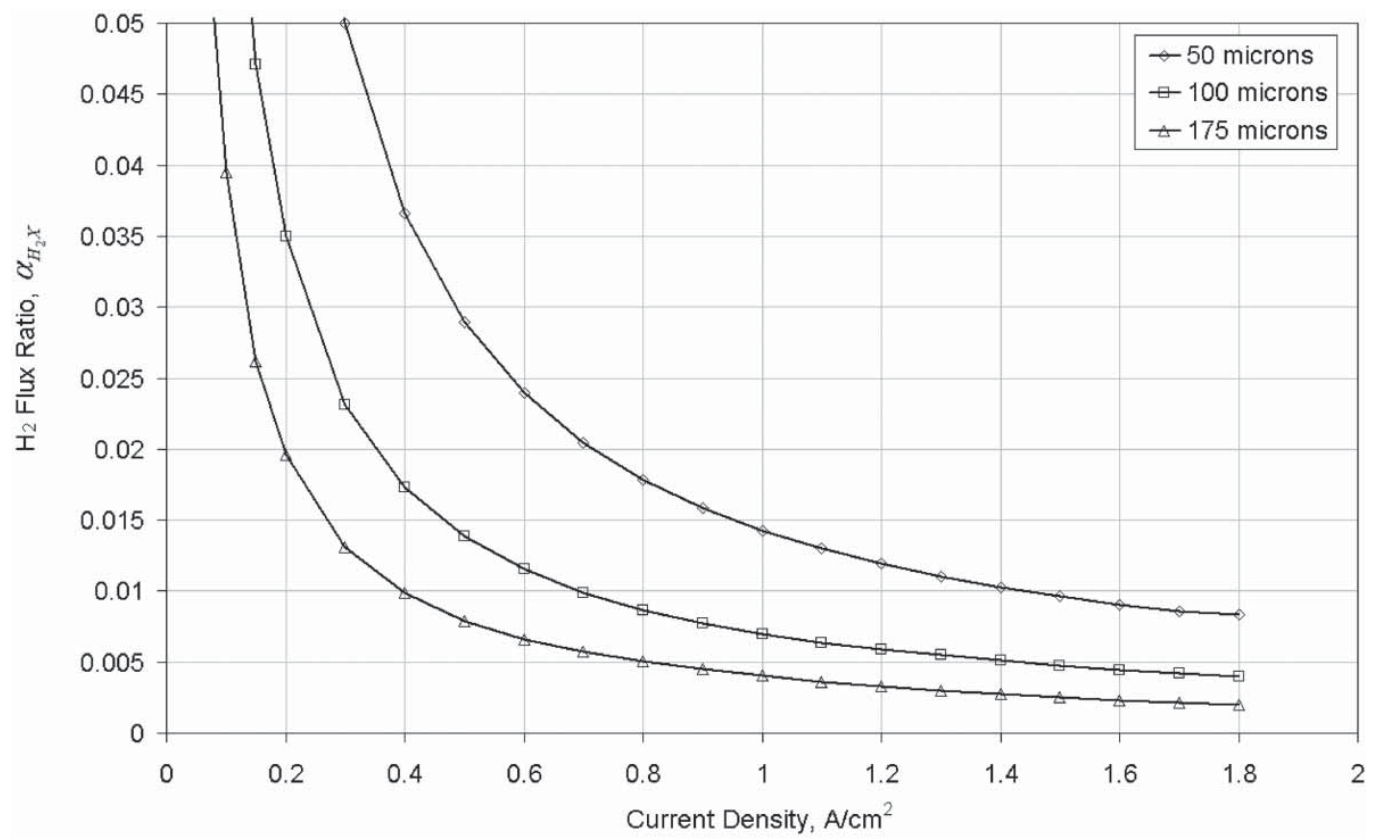

Fig. $5 \quad \mathrm{H}_{2}$ crossover as function of current density 


\section{CONCLUSIONS}

The literature identifies that there are predominantly three equations for modelling transport across the cell; the Nernst-Planck equation $[\mathbf{1 5}, \mathbf{2 0}]$; the diffusion equation in terms of chemical potential with an appended term for electro-osmotic drag [27]; and the Stefan-Maxwell type equation from CST $[42,43]$. The first two pertain to DST and are generally applicable for a solute species when its concentration is assumed to be much less than the solvent concentration. The third directly pertains to CST.

Using founding principles presented by Hirschfelder et al. [61], a general transport equation for concentrated solutions that includes a term for flux due to external fields has been developed in this work.

In the context of a fuel cell membrane, it is argued that it is a field in the electric potential that causes electro-osmotic drag of constituent species with zero valence because of the the hydrogen ion flux that occurs across it. Relative to a constituent species with zero valence, the field in electric potential is effectively an external field, and on this basis is included in the general transport equation to model multi-species electro-osmotic drag flux.

Theoretical validation has shown that the developed expression is consistent with all three existing key transport equations. This proves that the developed universal equation can be reduced to the two forms of DST (Nernst-Planck equation $[\mathbf{1 5}, \mathbf{2 0}]$ and the diffusion equation with explicit electro-osmotic drag [27]) for fuel cell membrane systems, and to the Stefan-Maxwell form of CST [42, 43].

In the context of a simple fuel cell model, the calculated results using the general transport equation for a three-species $(\mathrm{H}+$, water, electrolyte membrane) correctly predicts water content profiles that are consistent with published data. The calculated results predict that the water content is marginally less using the developed general transport equation in comparison with the results of Springer et al. [26], which can be attributed to DST. This is attributed to the dilute solution assumption that $c_{\mathrm{mem}} \approx c_{\mathrm{T}}$. Overall, the consistency with the published data shows that the general transport equation correctly predicts the molecular transport of water, including electro-osmotic drag flux.

Calculated results for a simple one-dimensional fuel cell with a four-component concentrated solution membrane system $(\mathrm{H}+$, water, electrolyte membrane, $\mathrm{H}_{2}$ ) give important results regarding the crossover of hydrogen. The general trend shows an increase in the crossover for thinner membranes and, for a fixed membrane thickness, a higher crossover at lower current densities.
For the nominal 1 atm case, the calculated results at $1 \mathrm{~A} / \mathrm{cm}^{2}$ suggest that the membrane thickness has to be in excess of $30 \mu \mathrm{m}$ to achieve a crossover rate equivalent to $5 \mathrm{~mA} / \mathrm{cm}^{2}$ or less. At $3 \mathrm{~atm}$, a similar decay in crossover with respect to increasing current density is observed. A 60 per cent drop in the crossover is observed by doubling the membrane thickness from 25 to $50 \mu \mathrm{m}$ at $353 \mathrm{~K}$. A further 72 per cent drop is observed when increasing the membrane thickness further to $175 \mu \mathrm{m}$ at the same temperature. At $383 \mathrm{~K}$, the diffusion coefficient of hydrogen in the membrane and in water increases, facilitating a marginal increase in the crossover for all membrane thicknesses.

Finally, the crossover for three different membrane thicknesses showed a significant reduction in crossover at all practical current densities for thicker membranes. The calculated results suggest that from the three thicknesses considered, the $175 \mu \mathrm{m}$ membrane is the most likely to offer equivalent crossover current densities of $5 \mathrm{~mA} / \mathrm{cm}^{2}$ or less in the practical operating range.

It is shown that the general transport equation, equation (22), can be used to model multi-species transport without the need to superimpose independent transport equations based on dilute solution relations such as Ficks law. It has been shown that this can be done in multi-component form while being able to accommodate explicitly for electroosmotically induced drag fluxes.

\section{REFERENCES}

1 Costamagna, P. and Srinivasan, S. Quantum jumps in the PEMFC science and technology from the 1960s to the year 2000; part I. Fundamental scientific aspects. J. Power Source., 2001, 102, 242-252.

2 Costamagna, P. and Srinivasan, S. Quantum jumps in the PEMFC science and technology from the 1960s to the year 2000; part II. engineering, technology development and application aspects. J. Power Source., 2001, 102, 253-269.

3 Baschuk, J. J. and Li, X. Carbon monoxide poisoning of proton exchange membrane fuel cells. Int. J.Energy Res., 2001, 25, 695-713.

4 Wang, J. T. and Savinell, R. F. Simulation studies on the fuel electrode of a H2-O2 polymer electrolyte fuel cell. Electrochem. Acta, 1992, 37, 2737-2745.

5 Chan, S. H., Goh, S. K., and Jiang, S. P. A mathematical model of polymer electrolyte fuel cell with anode CO. kinetics. Electrochem. Acta, 2003, 48, 1905-1919.

6 Baschuk, J. J., Rowe, A. M., and Li, X. Modelling and simulation of PEM fuel cells with CO Poisoning. Trans. ASME, 2003, 125, 94-100.

7 Amphlett, J. C., Baumert, R. M., Mann, R. F., Peppley, B. A., Roberge, P. R., and Rodrigues, A. The effect of carbon monoxide contamination on anode efficiency 
in PEM fuel cells. Am. Chem. Soc.: Div. Fuel Chem., 1993, 38, 1477-1482.

8 Oetjen, H. F., Schmidt, V. M., Stimming, U., and Trila, F. Performance data of a proton exchange membrane fuel cell using $\mathrm{H} 2 / \mathrm{CO}$ as fuel gas. J. Electrochem. Soc., 1996, 143, 3838-3842.

9 Dhar, H. P., Christner, L. G., Kush, A. K., and Maru, H. C. Performance study of a fuel cell Pt-on-C anode in presence of $\mathrm{CO}$ and $\mathrm{CO} 2$, and calculation of adorption parameters for CO poisoning. J. Electrochem. Soc., 1986, 133, 1547-1582.

10 Qi, Z., He, C., and Kaufman, A. Effect of CO in the anode fuel on the performance of the PEM fuel cell cathode. J. Power Source., 2002, 111, 239-247.

11 Springer, T. E., Rockward T, Zawodzinski, T. A., and Gottesfeld, S. Model for Polymer electrolyte fuel cell operation on reformate feed. J. Electrochem. Soc., 2001, 148, A11-A23.

12 Moore, J. M., Adcock, P. L., Lakeman, J. B., and Mepsted, G. O. The effects of battlefield contaminants on PEMFC performance. J. Power Source., 2000, 85, 254-260.

13 Okada, T. Theory for water management in membranes for polymer electrolyte fuel cells; part 1 . The effect of impurity ions at the anode side on the membrane performances. J. Electroanal. Chem., 1999, 465, $1-17$.

14 Okada, T. Theory for water management in membranes for polymer electrolyte fuel cells; part 1 . The effect of impurity ions at the cathode side on the membrane performances. J. Electroanal. Chem., 1999, 465, 18-29.

15 Bernardi, D. M. and Verbrugge, M. W. A mathematical model of the solid-polymer-electrolyte fuel cell. J. Electrochem. Soc., 1992, 139, 2477-2491.

16 Weber, A. Z. and Newman, J. Transport in polymerelectrolyte membranes; II. mathematical model. J. Electrochem. Soc., 2004, 151, A311-A325.

17 Li, Q., He, R., Jensen, J. O., and Bjerrum, N. J. PBIbased polymer membranes for high temperature fuel cells - preparation, characterisation and fuel cell demonstration. Fuel Cells, 2004, 4, 147-159.

18 Rama, P., Chen, R., and Thring, R. A polymer electrolyte membrane fuel cell model with multi-species input. Proc. Institute Mech. Engrs. Part A: J. Power and energy, 2005, 219, 255-271.

19 Ridge, S. J., White, R. E., Tsou, Y., Beaver, R. N., and Eisman, G. A. Oxygen reduction in a proton exchange membrane test cell. J. Electrochem. Soc., 1989, 136, $1902-1909$.

20 Bernardi, D. M. and Verbrugge, M. W. Mathematical model of a gas-diffusion electrode bonded to a polymer electrolyte. Am. Institute Chem. Engineers, 1991, 37, 1151.

21 Berndardi, D. M. Water-balance calculations for solidpolymer-electrolyte fuel cells. J. Electrochem. Soc., 1990, 137, 3344-3350.

22 Pisani, L., Murgia, G., Valentini, M., and D'Aguanno, B. A working model of polymer electrolyte fuel cells. J. Electrochem. Soc., 2002; 149, A898-A904.

23 Pisani, L., Murgia, G., Valentini, M., and D'Aguanno, B. Analytical pore scale modelling of the reactive regions of polymer electrolyte fuel cells. J. Electrochem. Soc., 2003, 150, A1549-A1559.
24 Murgia, G., Pisani, L., Valentini, M., and D'Aguanno, B. Electrochemistry and mass transport in polymer electrolyte fuel cells; I. model. J. Electrochem. Soc., 2002, 149, A31-A38.

25 Djilali, N. and Lu, D. Infuence of heat transfer on gas and water transport in fuel cells. Int. J. Therm. Sci., 2002, 41, 29-40.

26 Berning, T. and Djilali, N. Three-dimensional computational analysis of transport phenomena in a PEM fuel cell - a parametric study. J. Power Source., 2003, 124, 440-452.

27 Springer, T. E., Zawodzinski, T. A., and Gottesfeld, S. Polymer electrolyte fuel cell model. J. Electrochem. Soc., 1991, 138, 2334-2342.

28 Nguyen, T. V. and White, R. E. A water and heat management model for proton-exchange-membrane fuel cells. J. Electrochem. Soc., 1993, 140, 2178-2186.

29 Okada, T., Xie, G., and Meeg, M. Simulation for water management in membranes for polymer electrolye fuel cells. Electrochem. Acta, 1998, 43, 2141-2155.

30 Yi, J. S. and Nguyen, T. V. An along-the-channel model for proton exchange membrane fuel cells. J. Electrochem. Soc., 1998, 145, 1149-1159.

31 Nataranjan, D. and Nguyen, T. V. A two-dimensional, two-phase, multicomponent, transient model for the cathode of a proton exchange membrane fuel cell using conventional gas distributors. J. Electrochem. Soc., 2001, 148, A1324-A1335.

32 Nataranja, D. and Nguyen, T. V. Three-dimensional effects of liquid water flooding in the cathode of a PEM fuel cell. J. Power Source., 2003, 115, 66-80.

33 van Bussel, H. P. L. H., Koene, F. G. H., and Mallant, R. K. A. M. Dynamic model of solid polymer fuel cell water management. J. Power Source., 1998, 71, 218-222.

34 Siegel, N. P., Ellis, M. W., Nelson, D. J., and von Sparkovsky, M. R. A two-dimensional computational model of a PEMFC with liquid water transport. J. Power Source., 2004, 128, 173-184.

35 Chen, F, Su,Y.-G., Soong, C.-Y., Yan, W.-M., and Chu, H.-S. Transient behaviour of water transport in the membrane of a PEM fuel cell. J. Electroanal. Chem., 2004, 566, 85-93.

36 Yan, W.-M., Chen, F., Wu, H.-Y., Soong, C.-Y., and Chu, H.-S. Analysis of thermal and water management with temperature-dependant diffusion effects in membrane of proton exchange membrane fuel cells. J. Power Source., 2004, 566, 85-93.

37 Rowe, A. and Li, X. Mathematical modelling of proton exchange membrane fuel cells. J. Power Source., 2001, 102, 82-96.

38 Kulikovsky, A. A. Quasi-3D modeling of water transport in polymer electrolyte fuel cells. J. Electrochem. Soc., 2003, 150, A1432-A1439.

39 Ge, S.-H. and Yi, B.-L. A mathematical model for PEMFC in different flow modes. J. Power Source., 2003, 124, 1-11.

40 Sun, H., Liu, D., and Guo L-J. PEM fuel cell performance and its two-phase mass transport. J. Power Source., 2005, 143, 125-135.

41 Yu, X., Xhou, B., and Sobiesiak, A. Water and thermal management for Ballard PEM fuel cell stack. J. Power Source., 2005, 147, 184-195. 
42 Fuller, T. F. and Newman, J. Water and thermal management in solid-polymer-electrolyte fuel cells. J. Electrochem. Soc., 1993, 140, 1218-1225.

43 Fuller, T. F. and Newman, J. A Concentrated solution theory model of transport in solid-polymer-electrolyte fuel cells. Electrochem. Soc. Proc. Ser., 1989, PV 89-14, 25-38.

44 Janssen, G. J. M. A Phenomenological model of water transport in a proton exchange membrane fuel cell. $J$. Electrochem. Soc., 2001, 148, A1313-A1323.

45 Weber, A. Z. and Newman, J. Transport in polymerelectrolyte membranes; I. physical model. J. Electrochem. Soc., 2003, 150, A1008-A1015.

46 Weber, A. Z. and Newman, J. Transport in polymerelectrolyte membranes; III. model validation in a simple fuel-cell model. J. Electrochem. Soc., 2004, 151, A326-A339.

47 Meyers, J. P. and Newman, J. Simulation of the direct methanol fuel cell; I. thermodynamic framework for a multicomponent membrane. J. Electrochem. Soc., 2002, 149, A710-A717.

48 Meyers, J. P. and Newman, J. Simulation of the direct methanol fuel cell; II. modelling and data analysis of transport and kinetic phenomenon. J. Electrochem. Soc., 2002, 149, A718-A728.

49 Meyers, J. P. and Newman, J. Simulation of the direct methanol fuel cell; III. design and optimisation. J. Electrochem. Soc., 2002, 149, A729-A735.

50 Wohr, M., Bolwin, K., Schnurnberger, W., Fischer, M., Neubrand, W., and Eigenberger, G. Dynamic modelling and simulation of a polymer membrane fuel cell including mass transport limitation. Int. J. Hydrogen Energ., 1998, 23, 213-218.

51 Futerko, P. and Hsing, I.-M. Two-dimensional finiteelement method study of the resistance of membranes in polymer electrolyte fuel cells. Electrochem. Acta, 2000, 45, 1741-1751.

52 Hsing, I.-M. and Futerko, P. Two-dimensional simulation of water transport in polymer electrolyte fuel cells. Chem. Eng. Sci., 2000, 55, 4209-4218.

53 Thampan, T., Malhotra, S., Tang, H., and Datta, R. Modelling of conductive transport in proton-exchange membranes for fuel cells. J. Electrochem. Soc., 2000, 149, 3242-3250.

54 Eikerling, M., Kharkats, Y. I., Kornyshev, A. A., and Volfkovich, Y. M. Phenomenological theory of electro-osmotic effect and water management in polymer electrolyte proton-conducting membranes. J. Electrochem. Soc., 1998, 145, 2684-2699.

55 Meier, F. and Eignerberger, G. Transport properties for the modelling of water transport in ionomer membranes for PEM-fuel cells. Electrochem. Acta, 2004, 49, $1731-1742$.

56 Baschuk, J. J. and Li, X. Modelling of polymer electrolyte membrane fuel cells with variable degrees of water flooding. J. Power Source., 2000, 86, 181-196.

57 Amphlett, J. C., Baumert, R. M., Mann, R. F., Peppley, B. A., and Roberge, P. R. Performance modelling of the ballard mark IV solid polymer electrolyte fuel cell. $J$. Electrochem. Soc., 1995, 142, 1-8.

58 Mann, R. F., Amphlett, J. C., Hooper, M. A. I., Jensen, H. M., Peppley, B. A., and Roberge, P. R. Development and application of a generalised steady-state electrochemical model for a PEM fuel cell. J. Power Source., 2000, 86, 173-180.

59 Weber, A. Z. and Newman, J. Modelling in polymerelectrolyte fuel cells. Chem. Rev., 2004, 104, 4679-4726.

60 Wang, C.-Y. Fundamental models for fuel cell engineering. Chem. Rev., 2004, 104, 4727-4766.

61 Hirschfelder, J. O., Curtiss, C. F., and Bird, R. B. Molecular theory of gases and liquids, 1964 (John Wiley \& Sons, Inc., New York).

62 Newman, J. Electrochemical systems, 1973 (PrenticeHall, Inc., Englewood Cliffs, New Jersey).

63 Wang, Z. H., Wang, C. Y., and Chen, K. S. Two-phase flow and transport in the air cathode of proton exchange membrane fuel cells. J. Power Source., 2001, 94, 40-50.

64 Freire, T. J. P. and Gonzalez, E. R. Effect of membrane characteristics and humidification conditions on the impedence response of polymer electrolyte fuel cells. J. Electroanal. Chem., 2001, 503, 57-68.

65 Sena, D. R., Ticianelli, E. A., Paganin, V. A., and Gonzalez, E. R. Effect of water transport in a PEFC at low temperatures operating with dry hydrogen. J. Electranal. Chem., 1999, 477, 164-170.

66 Matsuyama, H., Matsui, K., Kitamura, Y., Maki, T., and Teramoto, M. Effect of membrane thickness and membrane preparation condition on facilitated transport of CO2 through ionomer membrane. Sep. Purif. Technol., 1999, 17, 235-241.

67 Hydrogen, Fuel Cells \& Infrastructure Technologies Program. US Department of Energy, 2005; DOE/GO102003-1741.

68 Slattery, J. C. and Bird, R. B. Calculation of the diffusion coefficient of dilute gases and of the selfdiffusion coefficient of dense gases. Am. Institute Chem. Eng., 1958, 4, 137-141.

\section{APPENDIX}

\section{Notation}

$c_{i} \quad$ concentration of species $i\left(\mathrm{~mol} / \mathrm{cm}^{3}\right)$

$d_{i} \quad$ molecular driving force ( $\mathrm{g} /$ molecule $\mathrm{J}$ )

$D_{i j} \quad$ diffusion coefficient of species $i$ in species $j$

$\left(\mathrm{cm}^{2} / \mathrm{s}\right)$

$D_{i}^{\mathrm{T}} \quad$ thermal diffusion coefficient of species $i$ $\left(\mathrm{cm}^{2} / \mathrm{s}\right)$

EW membrane equivalent weight (g/equiv.)

$f_{\mathrm{v}} \quad$ volume fraction of water in the membrane

$F \quad$ Faraday constant (C/equiv.)

I molar flux of water produced at the cathode $\left(\mathrm{mol} / \mathrm{cm}^{2} \mathrm{~s}\right)$

$J \quad$ current density $\left(\mathrm{A} / \mathrm{cm}^{2}\right)$

$k \quad$ Boltzman constant $(\mathrm{J} / \mathrm{K})$

$k_{\phi} \quad$ electrokinetic permeability $\left(\mathrm{cm}^{2}\right)$

$k_{\mathrm{p}} \quad$ hydraulic permeability $\left(\mathrm{cm}^{2}\right)$

$m_{\mathrm{i}} \quad$ molecular mass of species $i$ (g/molecule)

$M_{i} \quad$ molar mass of species $i(\mathrm{~g} / \mathrm{mol})$ 


\begin{tabular}{|c|c|c|c|}
\hline$n_{i}$ & $\begin{array}{l}\text { molecular concentration of species } i \\
\left(\text { molecules } / \mathrm{cm}^{3}\right)\end{array}$ & $\mu_{i}$ & $\begin{array}{l}\text { molecular electrochemical potential of } \\
\text { species } i(\mathrm{~J} / \mathrm{molec} \text { le) }\end{array}$ \\
\hline$\dot{n}_{i}$ & flux of species $i\left(\mathrm{~mol} / \mathrm{cm}^{2}-\mathrm{s}\right)$ & $\mu_{i}$ & molar electrochemical potential of species $i$ \\
\hline$N_{\mathrm{A}}$ & Avagadro number (molecules/mol) & & $(\mathrm{J} / \mathrm{mol})$ \\
\hline$p$ & pressure $(\mathrm{Pa})$ & $\xi_{i}$ & electro-osmotic drag ratio of species $i$ \\
\hline$R$ & universal gas constant $(\mathrm{J} / \mathrm{mol} \mathrm{K})$ & $\rho$ & density $\left(\mathrm{g} / \mathrm{cm}^{3}\right)$ \\
\hline$\overline{\boldsymbol{S}}_{l}$ & molecular entropy (J/molecule $\mathrm{K})$ & & \\
\hline $\bar{S}_{i}$ & molar entropy $(\mathrm{J} / \mathrm{mol} \mathrm{K})$ & \multirow{2}{*}{\multicolumn{2}{|c|}{ Subscripts }} \\
\hline$t_{\mathrm{m}}$ & membrane thickness $(\mathrm{cm})$ & & \\
\hline$T$ & temperature $(\mathrm{K})$ & $\mathrm{H}+$ & hydrogen ion \\
\hline$v_{i}$ & velocity of species $i(\mathrm{~cm} / \mathrm{s})$ & & species $i$ \\
\hline$V$ & $\begin{array}{l}\text { membrane and water molar volume } \\
\left(\mathrm{cm}^{3} / \mathrm{mol}\right)\end{array}$ & $j$ & species $j$ \\
\hline$V_{\mathrm{m}}$ & dry membrane molar volume $\left(\mathrm{cm}^{3} / \mathrm{mol}\right)$ & $\begin{array}{l}\mathrm{m} \\
n\end{array}$ & $\begin{array}{l}\text { membrane } \\
\text { oxidant or reductant species }\end{array}$ \\
\hline$V_{\mathrm{m}}$ & water molar volume $\left(\mathrm{cm}^{3} / \mathrm{mol}\right)$ & $\mathrm{T}$ & total value \\
\hline $\boldsymbol{X}_{l}$ & general molecular force $(\mathrm{J} / \mathrm{cm}$ molecule) & $\mathrm{W}$ & water \\
\hline$X_{i}$ & general molar force $(\mathrm{J} / \mathrm{cm} \mathrm{mol})$ & $\mathrm{X}$ & crossover \\
\hline$y_{i}$ & mole fraction of species $i$ & & \\
\hline$z_{i}$ & valence of species $i$ & \multicolumn{2}{|c|}{ Superscripts } \\
\hline & & A & anode \\
\hline$\alpha_{i}^{\mathrm{E}}$ & net flux ratio of species $i$ to species $n$ for & $\mathrm{C}$ & cathode \\
\hline & electrode E & $\mathrm{CH}$ & channel \\
\hline$\varepsilon$ & porosity & $E-1$ & interface 1 or 2 of electrode $E$ \\
\hline$\lambda$ & moles of water content per mole of charge & or 2 & \\
\hline & site & Sat & saturation \\
\hline$\Lambda_{i}$ & diffusive flux affinity for species $i(\mathrm{~J} / \mathrm{g} \mathrm{cm})$ & $\mathrm{T}$ & thermal property \\
\hline
\end{tabular}

